\title{
Modeling of water demand management in an arid area: case of Bechar city
}

\author{
Sara Seddiki ${ }^{1,2}$ (D) El Amine Cherif ${ }^{1,2}$
}

Received: 16 February 2021 / Accepted: 26 March 2021 / Published online: 20 May 2021

(c) The Author(s) 2021

\begin{abstract}
Bechar city is located in arid climate of the Algerian Sahara, with an average annual rainfall of about $72 \mathrm{~mm}$. There are two sources to ensure the water supply of the town of Bechar; the first comes from a watershed made up of eight non-renewable boreholes, and the second comes from the Djorf Torba dam, located about $45 \mathrm{~km}$ to the west. The pressure on water demand in the highland region depends on many factors, namely: demographic, social, climatic and economic. This study is based on the application of a water evaluation and planning computer tool on the city of Bechar. Which allows us to analyze the supply-demand balance in the water and assess the impact of different scenarios on the study area for manage the water resource and the projected water demand for the different sectors (drinking water, industrial water and agriculture) until 2060.
\end{abstract}

Keywords Algerian Sahara $\cdot$ Water resources $\cdot$ Management $\cdot$ Water evaluation and planning (WEAP) $\cdot$ Different scenarios $\cdot$ Climate change

\section{Abbreviations}

ADE Algerian waters

ANRH National hydraulic resources agency

DRE Water resources department

\section{Introduction}

Information on hydrological bowls is vital, as they establish the overall system and fundamental unit of hydrological explore and can give data on catastrophic events or water delicacy. The issue in the present bone-dry districts is the inadequate advancement of water assets and the absence of comprehension of the capable individual. Unfortunately, in recent years, our region has had difficulties in ensuring adequate hydrological control of the Wadi Bechar basin and its tributaries due to the reduction in the number of meteorological stations. (There is only one rain station and

Sara Seddiki

sara82002dz@yahoo.fr

1 Department of Hydraulic, University of Science and Technology Oran - Mohamed Boudiaf Oran, Oran, Algeria

2 Laboratory of Management and Water Treatment, (LGTE), University of Science and Technology Oran - Mohamed Boudiaf, Oran, Algeria one active hydrometric station.) Sometimes, due to lack of human and financial resources, these stations are considered insignificant. In particular, in our region, the data relating to water resources and their seasonal variations show weaknesses with distorted hydrological databases. The flow periods available for reliable hydrological analysis are often incomplete, discontinuous, short-lived and therefore difficult to exploit, and hydrological models have an interest in overcoming these problems.

The lack of adequate information on the wadi Bechar watershed is a major inconvenience for researchers of the area for development. Today, the use of water for domestic and industrial purposes is increasing, threatening its sustainability and having negative consequences on agriculture, forestry, industry and drinking water supply (Alibou 2002; Jasortia et al. 2012). Indeed, the current situation of aquifer systems has become a key area of concern. The quantitative and qualitative state of aquifers results from a combination of natural and anthropogenic factors. In addition, the duality between the demands of operators in this category of water and the need to ensure their sustainability is a challenging issue (sadat et al. 2020). Like the inland cities, the Bechar urban area has been on the threshold of water stress in recent decades, due to a soaring population of inhabitants [programming direction and budget monitoring 2014, climate change and excessive use. The study region, which is located in South-West Algeria, where the climate is arid, 
groundwater tables are the main source of supply for people, the largest and most demanding of which is the Turonian groundwater, which provides more than $30 \%$ of drinking water and irrigation needs (Kabour et al. 2011).

\section{Materials and methods}

\section{Study area}

The methodology adopted in this study was based as a first step on the collection and analysis of hydrological data and water demand as well as physical and hydraulic data from the wadi Bechar watershed system. Data collected from different organizations such as ADE, ANRH, DRE of the province of Bechar. Processing tools are also used to adapt all the data to the formats requested by the WEAP environment. The region of Bechar is located in the south-western part of the Algerian Sahara and is bordered to the north by the Algerian-Moroccan border, to the west and south-west by the Hammada de Guir, to the east by the large Erg Occidental and to the South by the Ugarta chain. It foresees a vast area with a combination of three morphological sets:

- The rugged mountainous area: djebels.

- The tabular ensemble: desert plateau called "Hammada."

- The whole in a bowl: depressions.

Bechar is surrounded by a mountain range: (Fig. 1) The Djebel Antar at $1953 \mathrm{~m}$, the Djebel Grouz at $1835 \mathrm{~m}$ and the Djebel Bechar at $1206 \mathrm{~m}$.

The population of the city of Bechar is 199,600 inhabitants in 2014. The wadi of Bechar begins at an altitude of $1919 \mathrm{~m}$ in the Djebel Grouz through wadi El Biodh. After a rapid descent, it receives in its course the waters of wadi R'tem, wadi Roknet El Betoum, as well as the waters of many tributaries coming from Djebel Antar, Arride and Djebel Bechar. After traveling about fifty kilometers, it passes through the town of Bechar and receives the waters of Oued Tigheline. Beyond the city, the wadi covers a hundred
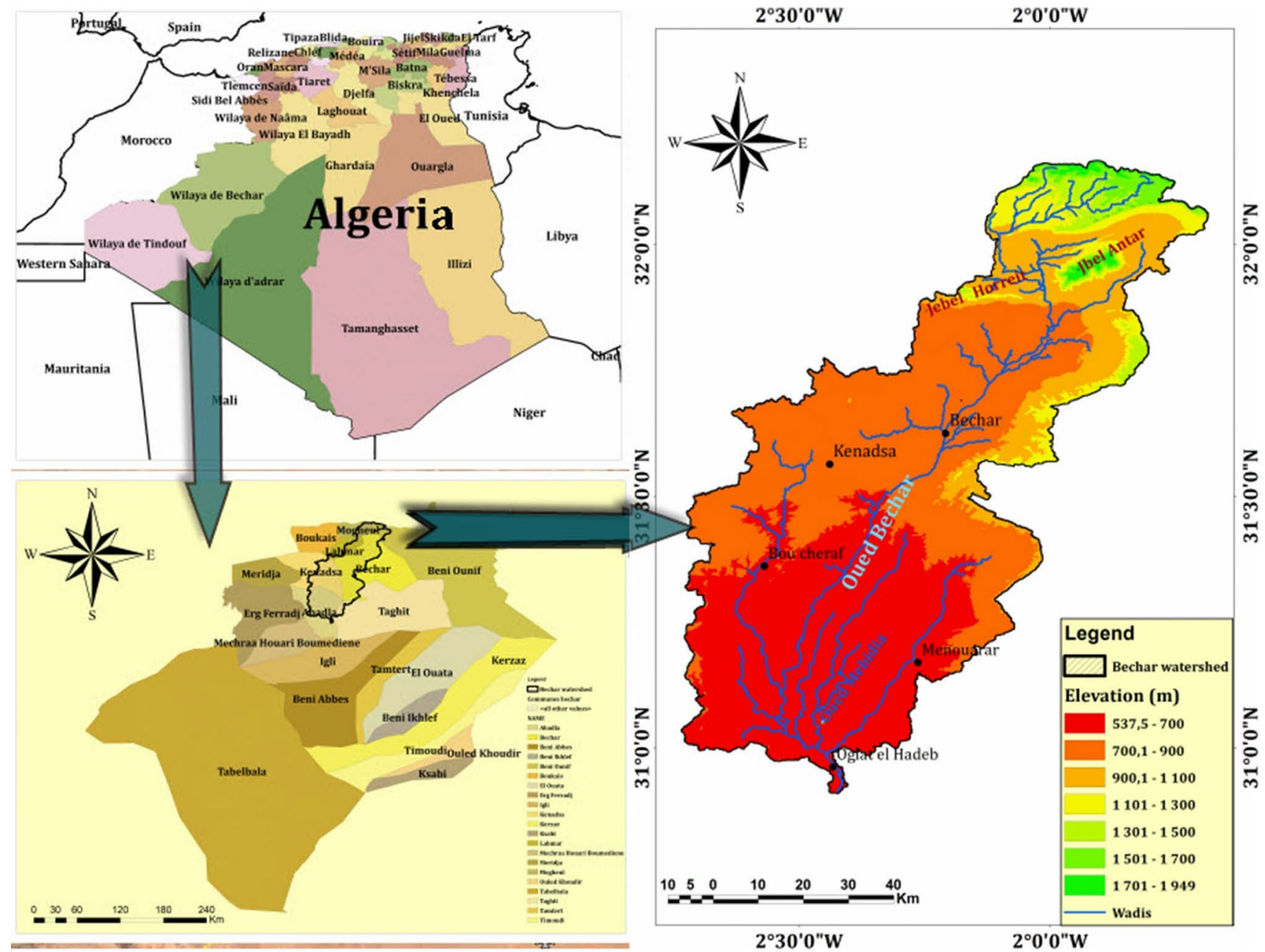

Fig. 1 Geographical location of the Wadi Bechar watershed (Bekhira et al. 2014) 
kilometers in a NE-SW direction, going from 900 to $600 \mathrm{~m}$ in altitude. At Ksiksou, it heads NW-SE and settles in sand at Daïet Tiour, at an altitude of $547 \mathrm{~m}$. The Algerian Sahara is characterized by significant climatic variations (Fig. 2). Aridity is the central element of Saharan specificity, it is defined as the result of the combination of low precipitation and the intensity of evaporation phenomena linked to high temperatures. (kendouci et al. 2019) (Fig. 2).

The climate of the study region is based on the information collected at the Bechar meteorological station (Table 1). The analysis of the various climatological parameters $(P$, $T{ }^{\circ} \mathrm{C}$, ETP, wind speed, etc.) specifies the climate which characterizes the region (Table 1).

\section{Water resource}

The drinking water supply network of Bechar city extends over $522 \mathrm{~km}$. And the supply water comes to two main sources: the first dam Djorf Torba (surface water) at a rate of $32,000 \mathrm{~m}^{3} / \mathrm{d}$; and the second Ouakda aquifer (groundwater) at a flow rate of $8000 \mathrm{~m}^{3} \mathrm{~d}$ with a flow rate of $4320 \mathrm{~m}^{3} / \mathrm{d}$ of Moughel drilling at a total underground flow of $12,320 \mathrm{~m}^{3} / \mathrm{d}$. For the gravity and pressure adduction, works are used as a treatment station; pumping station of $15,552 \mathrm{~m}^{3} / \mathrm{d}, 11$ storage and distribution tanks with a total capacity of 26,350 $\mathrm{m}^{3}$ (Kendouci 2019).

\section{Surface water}

The city of Bechar is supplied by surface water from the Djorf Torba dam, its reservoir capacity is $360 \mathrm{Hm}^{3}$. It is located $45 \mathrm{~km}$ west of the Bechar capital; it is diverted, mainly, to the drinking water supply of the city of Bechar and secondarily to irrigation for the agricultural perimeter of Abadla.
Fig. 2 Ombrothermal diagram of Gaussen of Bechar city (kendouci et al. 2019)

Table 1 Monthly climate in 2014

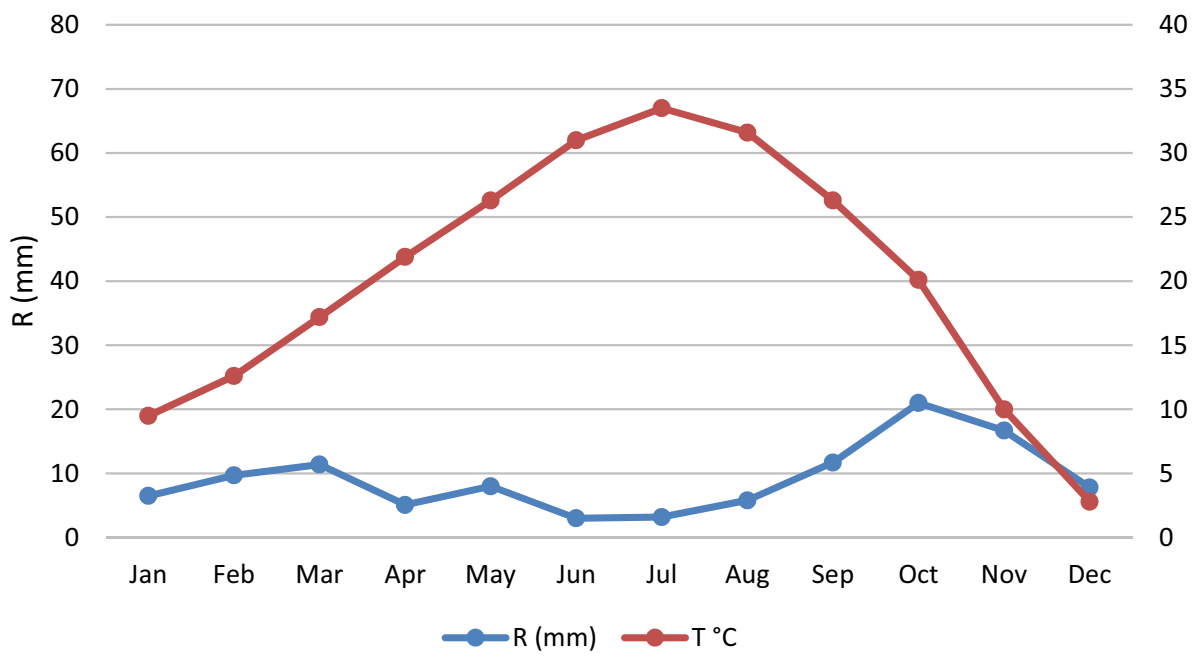

\begin{tabular}{llllr}
\hline Month/Parameter & Rainfall $(\mathrm{mm})$ & Evaporation $(\mathrm{mm})$ & $\begin{array}{l}\text { Temperature } \\
\left({ }^{\circ} \mathrm{C}\right)\end{array}$ & Wind $(\mathrm{m} / \mathrm{s})$ \\
\hline January & 6 & 122.47 & 9.5 & 5 \\
February & 6.8 & 98.29 & 11.8 & 4 \\
March & 10.8 & 134.01 & 17.5 & 8 \\
April & 4.8 & 166.34 & 21.1 & 15 \\
May & 5.2 & 214.86 & 21.4 & 14 \\
June & 4.2 & 248.79 & 31.6 & 12 \\
July & 1.6 & 320.41 & 35 & 8 \\
August & 3.05 & 362.78 & 33.8 & 4 \\
September & 14.4 & 304.02 & 28 & 5 \\
October & 27.9 & 244.84 & 21.7 & 2 \\
November & 11.1 & 195.48 & 14.5 & 2 \\
December & 6 & 167.75 & 11 & 1 \\
\hline
\end{tabular}

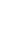




\section{Groundwater}

The region is landlocked on the south-eastern edge of an important geological entity, known as the Cretaceous basin of Er Rachidia-Bechar, which straddles Morocco and Algeria and which covers more than $8000 \mathrm{~km}^{2}$. It is commonly called the pre-African basin. The Algerian part is known under the name of the Cretaceous basin of Bechar, with an area of $4000 \mathrm{~km}^{2}$, the structure of which is an elongated East-West syncline. This basin is limited to the north by the Algerian-Moroccan border and the northern Carboniferous massifs (Djebel Horreit and Djebel Antar), to the east by the Jebel Bechar, to the south by the Chebka Mennouna and to the west by the Hamada de Guir and the Algerian-Moroccan border. Data from boreholes and outcrops at Ouakda suggest that on a carboniferous bedrock rests in angular discordance the Cretaceous and tertiary formations.

Ouakda aquifer (groundwater) at a flow rate of $8000 \mathrm{~m}^{3} / \mathrm{d}$ with a flow rate of $4320 \mathrm{~m}^{3} / \mathrm{d}$ of Moughel drilling at a total underground flow of $12320 \mathrm{~m}^{3} / \mathrm{d}$ (Kendouci 2019).

\section{Methods}

We chose the WEAP approach because the management of water resources requires knowledge of the current and future state of these resources in order to model the available resources and the drinking water needs of the population of the city of Bechar.

Running the WEAP requires the input of a large database for every element in the network. The data structure and level of detail may be easily customized to meet the requirements of a particular analysis and to reflect the limits imposed when data are limited (Yates et al. 2005).

\section{Input data}

The methodology adopted was based, first, on the construction of a cartographic database. Secondly, a conceptual model of the surface water mobilization system is developed using the WEAP software (Abdelbaki et al. 2017). The third step was to establish relationships between the nodes of the conceptual model with the database. This step calculates the water in and out for each node and links in the system during that month. This includes supply calculations to meet demand. For this, WEAP uses linear programming to solve the corresponding equations. The equilibrium equations represent the monthly basis of the water balance in WEAP. This work led to the construction of a tool for modeling the water needs of the city of Bechar. Analysis of development scenarios. The year 2014 was chosen as the reference for all the information on the system: application sites, supply data, consumption, links and transmission. Economic information, demography and water use are used to construct alternative scenarios that examine how total and disaggregated water use changes over time. Repeated simulations for different management scenarios can significantly expand the set of indicator values, creating a complicated analytical framework and imposing difficulties in recognizing the best or most desired scenario (SEI 2008). Are calculated in WEAP and applied deterministically to an allocation algorithm based on a linear program. Demand analysis is the starting point for conducting an integrated water planning analysis, since all supply and resource calculations in WEAP are carried out by the optimization routine that determines the final delivery at each request node, based on user-specified priorities (Bouznad et al. 2020). In this part, the parameters year and period of study, parameters and time units should be set, we limit the year of current accounts between 2014 and 2060 for all information on the system (request sites, supply data, ...).

\section{Results and discussion}

\section{The city of Bechar}

From this (Fig. 3), it follows that the evolution of the population is constantly growing by following the approach of the WEAP model, the population of the system studied will be of the order of 550,000 inhabitants in 2060.

\section{Water demand}

The assessment of the impact of the main factors, with a view to an integrated approach to the development of water supply in the context of water demand, its quality and the preservation of ecosystems, is envisaged through the creation scenarios or variants in the WEAP model. These scenarios are developed by the introduction of mathematical expressions in the form of key hypotheses reflecting the different scenarios to be examined. Remember that the year "Current or initial account" is used as the base year for the program. The "Reference" variant represents a simulated change without any influence from the year "Current accounts." Many variants can be created and simulated by introducing modifications to the "Reference" variant to assess. The effects due to changes in management rules and technologies. It is for this purpose that in our work, we have established the following scenarios:

1. Reference variant;

2. High population growth scenario;

Remember that the evolution of water demand depends on the size of the water- consuming elements (population, 
Fig. 3 Presentation of model WEAP (SEI 2008)
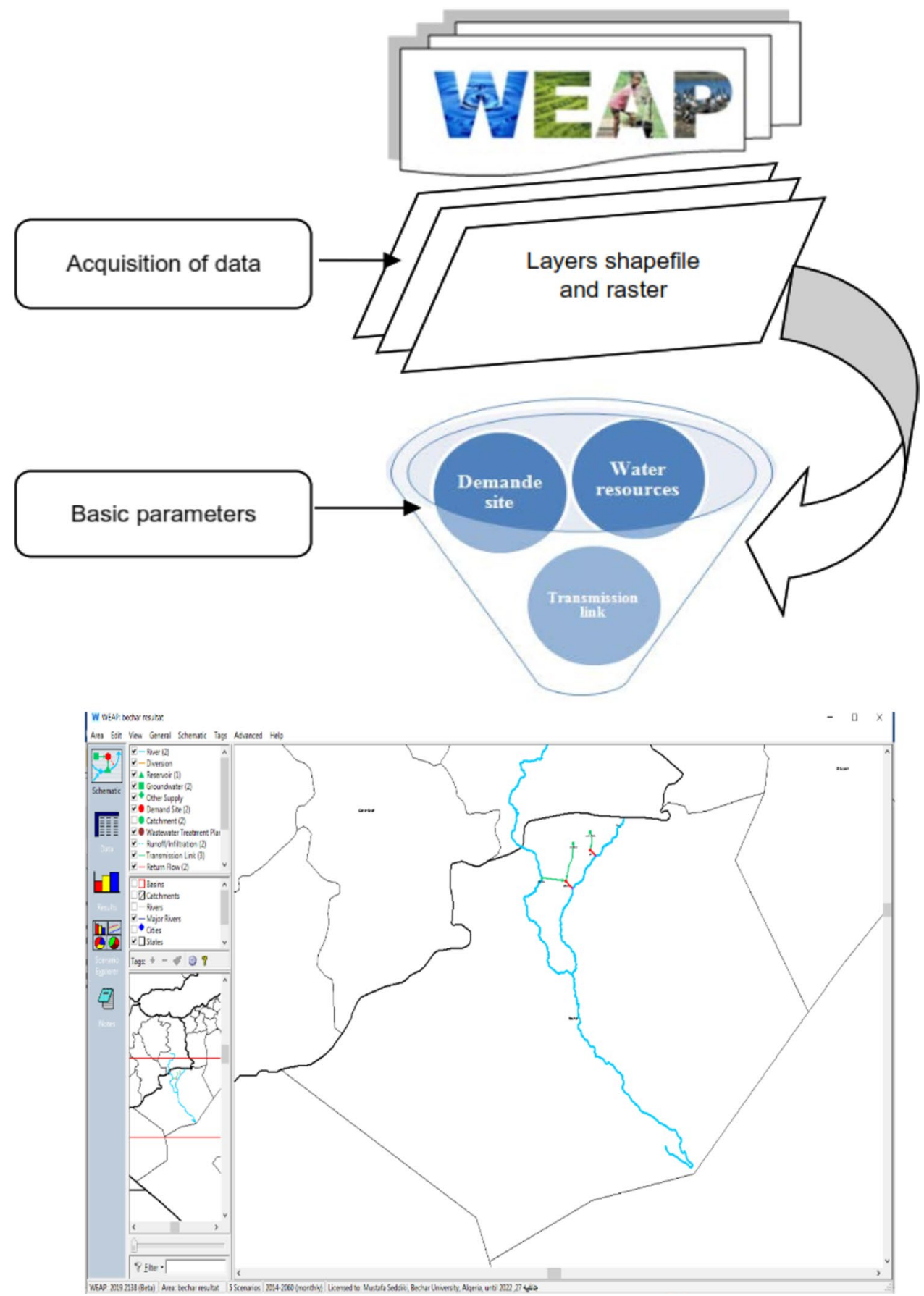

industry, irrigation, etc.), their rate of growth or development and their daily endowment. Figure below shows the evolution of water demand in the various sectors (domestic, industrial and irrigation). As for Fig. 4, it shows the monthly distribution of this demand in the year 2060.

The locations of the application are represented by the current population count calculated by the WEAP software using the number of population of the 2014 census for the base year 2014 and the growth rate. Given the demographic growth of urban areas, the demand for drinking water for the reference scenario continues to increase between 2015 and 2040: It increased by 37 million $\mathrm{m} 3$ in 2020, reaching in 2040 around 57 million $\mathrm{m}^{3}$ and will reach a total of "about 88 million $\mathrm{m} 3$ in 2060". The graph cited below (Fig. 5, 6) shows that the city of Bechar, this is explained by the high population and the way of life of this city (Fig. 6).

The total water demand also increases from 2015 to 2050 in all scenarios where the demand is highest during the period April to October. This increase is due to the intensive use of water laying in the summer, and the decline in 


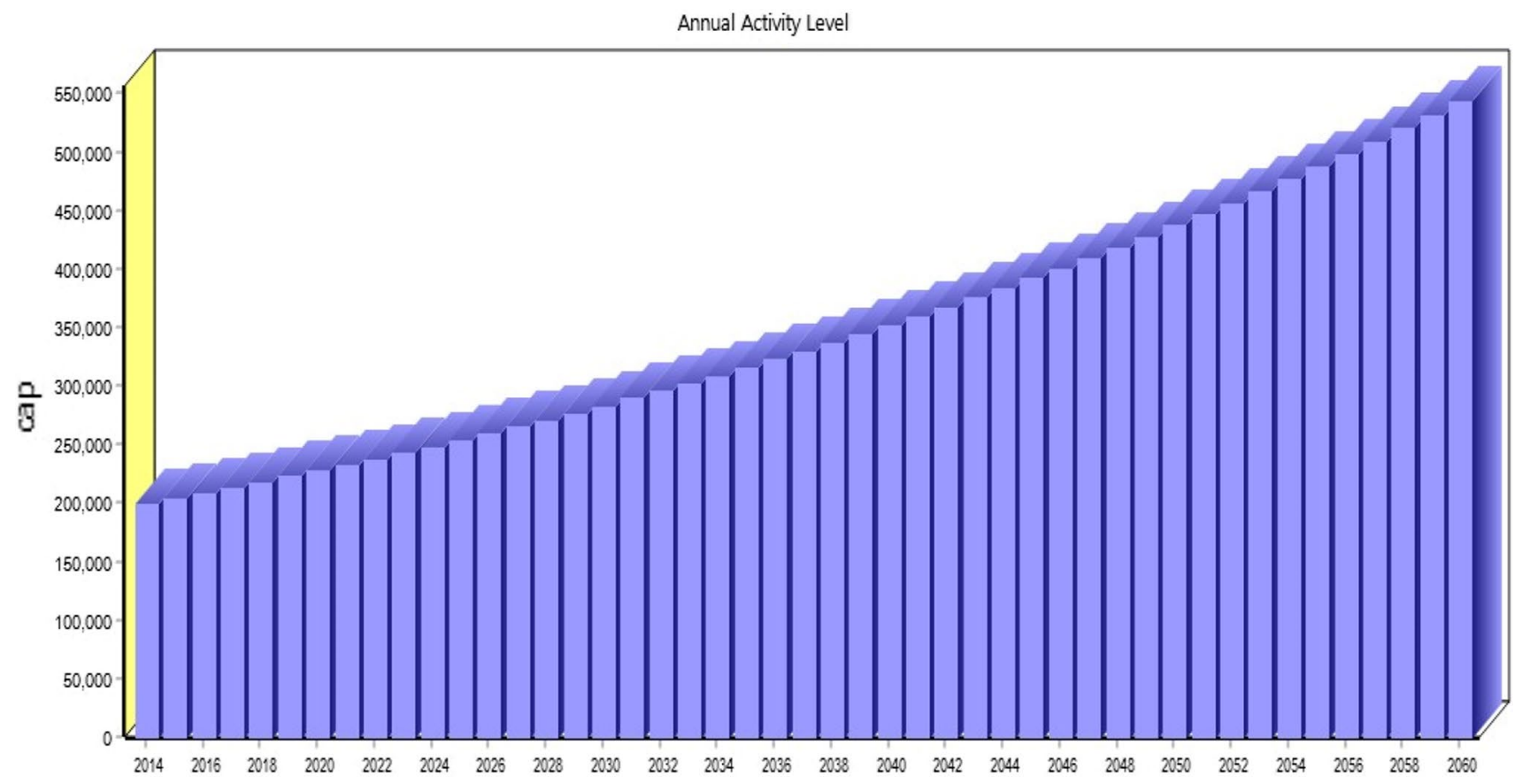

Fig. 4 Evolution of the number of inhabitants in the 2014-2060 reference scenario (rates 2.2\%)

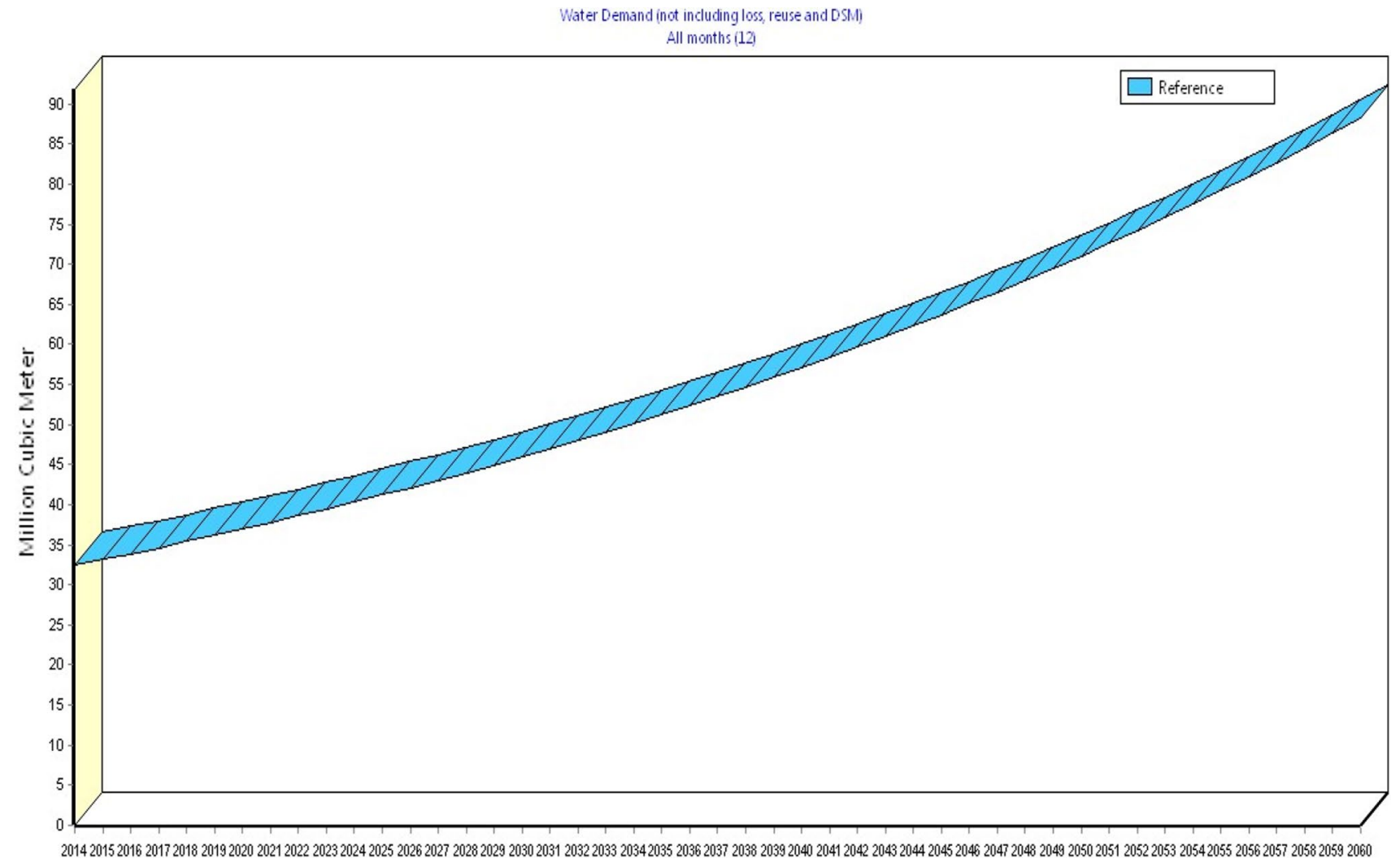

Fig. 5 Evolution of water demand in Bechar city—reference scenario; source: own study 


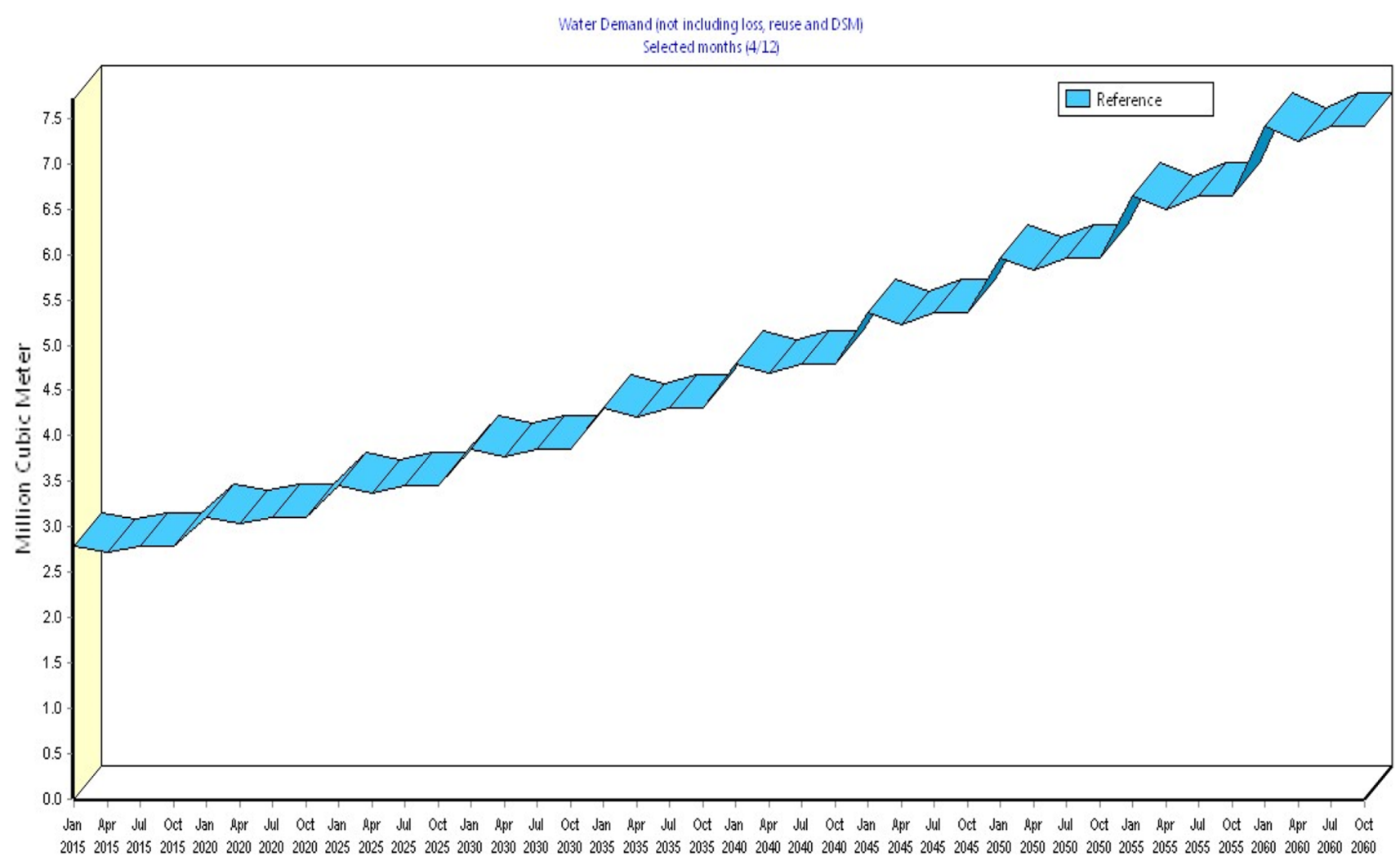

Fig. 6 Evolution of the monthly water demand in Bechar city—reference scenario; source: own study

resources due to climate change such as very high evaporation in surface resources as well as the problem of nonrenewable groundwater. The results obtained show that the water demand in July 2020 varied between 3 million $\mathrm{m}^{3}$ for the reference scenario and 4 million $\mathrm{m}^{3}$ for the population increase scenario (Fig. 7). The water requirements for the scenarios show a significant increase from of January 2045 12 million $\mathrm{m}^{3}$. This development will continue to reach 26 million $\mathrm{m}^{3}$ in July 2060. This demographic growth influences the water recources of the study area.

The gradual increase in water demand for this scenario is due to the combination of population pressure and water scarcity due to climate change (Fig. 7).

\section{Unmet demand}

The results of unmet demand show a deficit in drinking water for all scenarios. This deficit is clearly visible in the reference scenario where demand is not satisfied during the entire simulation period, with significant values of around 9 million $\mathrm{m}^{3}$ in 2035, exceeds 15 million $\mathrm{m}^{3}$ in 2045 and exceeds 32 million $\mathrm{m}^{3}$ in 2060 (Fig. 8). Note that the average endowment of $180 \mathrm{l} / \mathrm{d} /$ Person in 2015 will be at a higher rate compared to the baseline scenario, making the unmet demand visibly lower with a difference of 28 million $\mathrm{m}^{3}$.

\section{Conclusion}

Water is an infinite resource, and it will be necessary to reverse the strategy of adjusting supply to demand, so that it depends on supply while ensuring the success of other forms of water use. Unconventional resources, such as the use of treated wastewater.

The demand for water in arid area depends on many factors, namely demographic, social, climatic and economic factors. These factors lead to instability of water resources, which leads to water scarcity in urban areas. This study used an integrated water management model, WEAP, to model water demand and create scenarios to assess future water availability in the city of Bechar.

This study showed that the method for using an accessible modeling tool to integrate hydrological, hydrogeological and demographic data to facilitate decision making in water management.

The results of the WEAP model show that water scarcity is a challenge in this region, the effects of climate change and demographic pressures show a very significant 


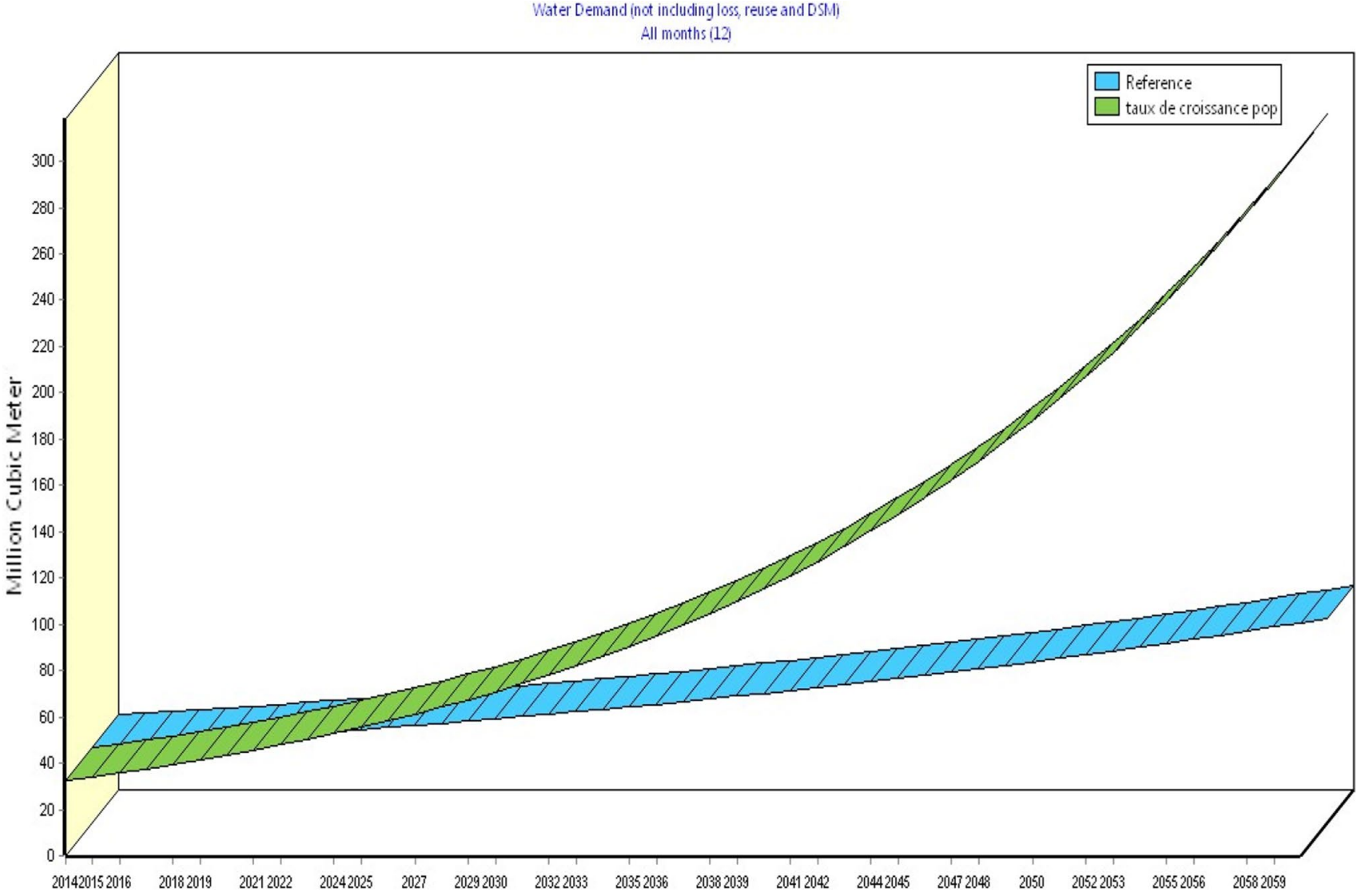

Fig. 7 Evolution of water demand in Bechar city—all scenarios; source: own study

deficit, exceeding 28 million $\mathrm{m}^{3}$ in 2060 . The return flow increases according to the evolution of the consumption needs of the sites.

These problems can be solved by the implementation of a new strategy based on the management of the water demand, the sensitization of the users to the saving of water, the improvement of the distribution networks and the diversification of the resources in water. Depending on the results of the ebbs, these resources can be used to meet the water needs of agriculture or industry or to artificially replenish aquifers. Another advantage of this measure is the protection of the environment against pollution and diseases that can be transmitted by contaminated water.

We can say that the drinking water supply of the city of Bechar has undergone several changes which are mainly due to the balance between available resources and needs, climate and population, we must therefore suggest some recommendations:

- The use of unconventional sources, in addition to the construction of dams and dams on the hills to preserve this scarce and exhaustible resource, has become inevitable.

- Water transfer, the solution that was chosen for the development of the region.

- To deepen the state of knowledge on water resources and develop a fundamental technical document, leading to the integrated management of these resources.

- Establish a detailed demographic study at the level of the consumption zone is necessary to understand the evolution of water consumption and to manage it better. 


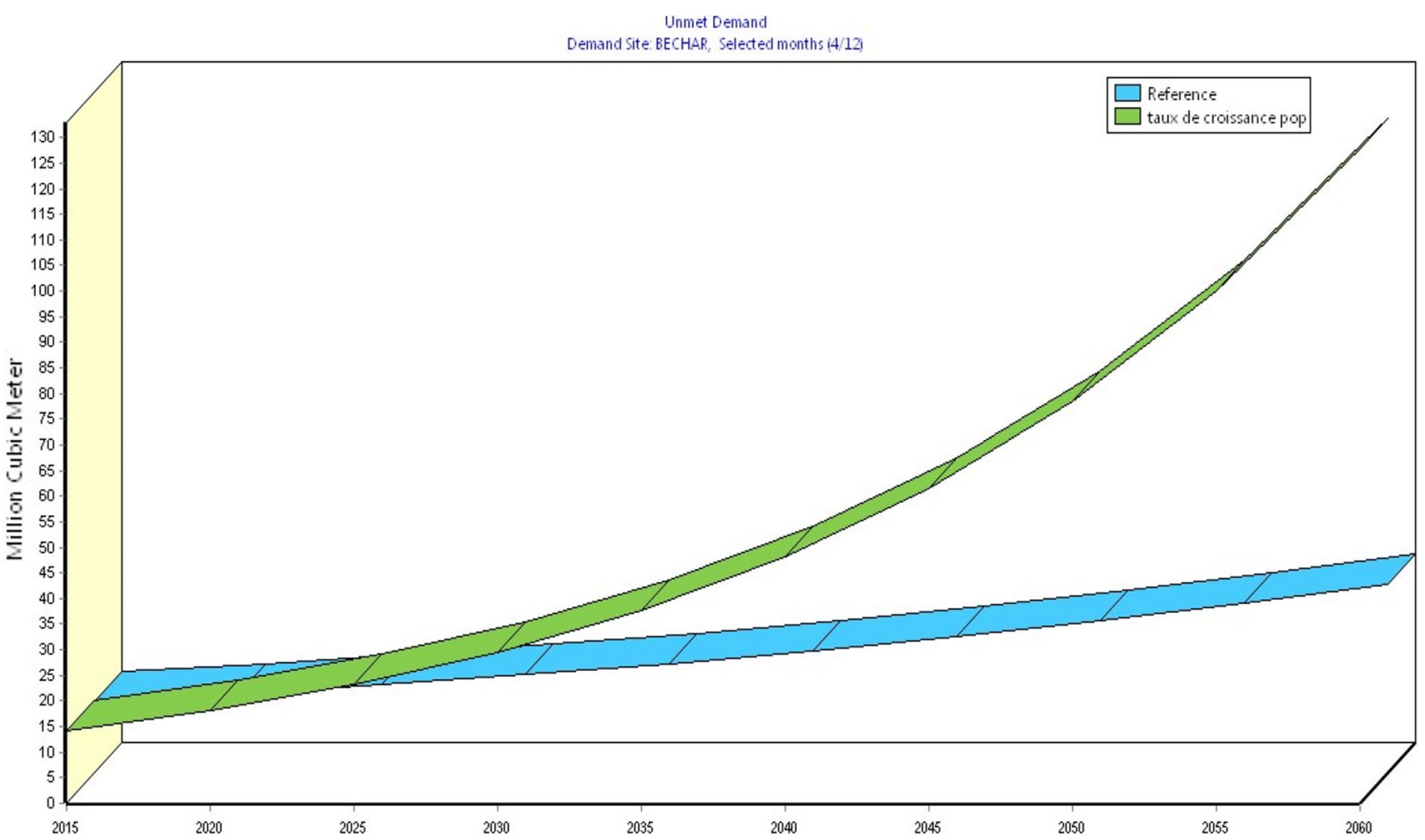

Fig. 8 Evolution of unmet water demand in the Bechar city—all scenarios; source: own study

Acknowledgements The authors would like to express their gratitude to the MESRS of Algeria, for the support.

Funding This study was funded by author.

\section{Declarations}

Conflict of Interest The authors declare that they have no conflict of interest.

Open Access This article is licensed under a Creative Commons Attribution 4.0 International License, which permits use, sharing, adaptation, distribution and reproduction in any medium or format, as long as you give appropriate credit to the original author(s) and the source, provide a link to the Creative Commons licence, and indicate if changes were made. The images or other third party material in this article are included in the article's Creative Commons licence, unless indicated otherwise in a credit line to the material. If material is not included in the article's Creative Commons licence and your intended use is not permitted by statutory regulation or exceeds the permitted use, you will need to obtain permission directly from the copyright holder. To view a copy of this licence, visit http://creativecommons.org/licenses/by/4.0/.

\section{References}

Abdelbaki C, Benchaib MM, Benziada S, Mahmoudi H, Goosen M (2017) Management of a water distribution network by coupling GIS and hydraulic modeling: a case study of Chetouane in
Algeria. Appl Water Sci 7(3):1561-1567. https://doi.org/10.1007/ s13201-016-0416-1

Alibou J (2002) Impact des changements climatiques sur les ressources en eau et les zones humides du Maroc (Impact of climate change on water resources and wetlands in Morocco). Centre d'étude et de recherche sur les systèmes hydrauliques et environnementaux, pp. 42

Bekhira A, Nebou M, Merzougi T (2014) Flood management in the Wadi Bechar watershed: hydrological study and development. Dissertation of Master. University of Bechar, Algeria, p. 159

Bouznad IE, Elahcene O, Belksier MS (2020) Management model for water demand using the WEAP tool: case of Setif ProvinceAlgerian highlands. J Water Land Dev 45(4-6):19-28

Essay of Modelling water resources management of the Oued Righ watershed (Algeria) using the WEAP decision support system Imad Eddine Bouznad; Derradji Zouini, Issam Nouiri and Fayçal Khelfaoui

Jasrotia AS, Bhagat BD, Kumar A, Kumar R (2013) Remote sensing and GIS approach for delineation of groundwater potential and groundwater quality zones of Western Doon Valley, Uttarakhand, India. J Indian Soc Remote Sens 41(2):365-377. https://doi.org/ 10.1007/s12524-012-0220-9

Kabour A, Hani A, Mekkaoui A, Chebbah L (2011) Evaluation et gestion des ressources hydriques dans une zone aride. Cas de la ville de Béchar (sud-ouest Algérien) [Assessment and management of water resources in arid zone

Kendouci MA, Bendida A, Mebarki S, Kharroubi B (2019) Study of the management efficiency of the drinking water supply in arid areas: case of Bechar city (southwest of Al- geria). Appl Water Sci 9:192. https://doi.org/10.1007/s13201-019-1081-y

Sadat S, Mansour H, Mekkaoui A, Merzougui T (2020) Identification and evolution of the Turonian aquifer case study: cretaceous

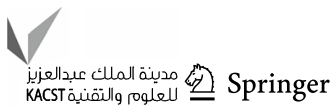


basin of Béchar, southwestern Algeria. J Water Land Dev 46(7-9):190-199

SEI (2008) WEAP (Water Evaluation and Planning): User Guide for WEAP21. Stockholm Environment Institute, Boston

Yates D, Sieber J, Purkey D, Huber-Lee A (2005) WEAP21-A demand-, priority-, and preference-driven water planning model: part 1: model characteristics. Water Int 30(4):487-500. https:// doi.org/10.1080/02508060508691894

Publisher's Note Springer Nature remains neutral with regard to jurisdictional claims in published maps and institutional affiliations. 